\title{
SATISFACTION OF VISITORS WITH FOOD OFFER AT GASTRONOMIC FESTIVALS IN RURAL AREAS
}

\author{
Danijela Stojanović ${ }^{1}$, Milena Vukić ${ }^{2}$, Ksenija Vukić3, Velibor Jovanovićc \\ *Corresponding author E-mail: milena.vukic12@gmail.com
}

A R T I C L E I N F O
Review Article
Received: 22 February 2020
Accepted: 15 May 2020
doi:10.5937/ekoPolj2002523S
UDC 338.48-44(1-22)
[641/642:06.078

Keywords:

Gastronomic festivals, local food, rural area, satisfaction, Serbia

JEL: O18,P25, Z32, Z33

\begin{abstract}
A B S T R A C T
The purpose of this paper is to explore visitors experience, habits and attributes that have significant impact on their satisfaction with food offer at "Plum Fair" held in Osečina. Collected data were analyzed and interpreted using some basic descriptive statistics techniques as well as nonparametric test such as Spearman's Rho. The results of the study showed that the majority of visitors come from the surrounding municipalities, motivated by the preservation of traditions and countryside. Purchase of food products was motivated by novelty as well as supporting local producers. Visitors were most satisfied with the taste of food products and least satisfied with their price. It might be noted that the rural gastronomic festivals and products have a great promotional and entrepreneurial potential by offering these products in the local restaurants as well as retail chains, which would positively affect the revitalization of rural area of Western Serbia.
\end{abstract}

(C) 2020 EA. All rights reserved.

\section{Introduction}

Gastronomy is defined as the scientific discipline that explore the historical development of nutrition, tradition of preparing and presenting the food of particular regions (Vukić, 2008). In order to preserve the identity of one's own nation, it is necessary to know the gastronomic history as well as eating habits of its people. On the other hand, knowing

1 Danijela Stojanović, Ph.D. candidate at the Faculty of Hotel Management and Tourism, University of Kragujevac, Vojvođanska 5A, 36210 Vrnjačka Banja, Serbia, Phone: +381628036723, e-mail: danijela.stojanovic@vhs.edu.rs, ORCID ID (https://orcid.org/0000-0001-9501-8550)

2 Milena Vukić, Ph.D., Professor of applied studies, Academy of Applied Studies Belgrade, College of Hotel Management, Kneza Višeslava 70, Belgrade, Serbia, Phone: +381628036709, e-mail: milena.vukic12@gmail.com ORCID ID (https://orcid.org/0000-0002-9423-9033)

3 Ksenija Vukić, MSc, Electric power industry of Serbia, Balkanska 13, Belgrade, Serbia, Phone: +381628036701, e-mail: xenija26@gmail.com, ORCID ID(https://orcid.org/0000-0002-5678-4356)

4 Velibor Jovanović, Ph.D., Teaching assistant, Military Academy, University of Defense Belgrade, Generala Pavla Jurišića Šturma 33, Belgrade, Serbia, Phone: +381603497493, e-mail: velibordjovanoive@gmail.com, ORCID ID (https://orcid.org/0000-0003-0036-4616) 
the eating habits of other nations and exchange of experiences with them is an important prerequisite for keeping up with global culinary trends. The importance of gastronomy as the main component of the tourist product, can be seen especially in the fact that many users find it a leading motive when discovering new destinations. Gastronomic tourism could represent an added value to general experience of the existing tourist offer (Sims, 2009), so it becomes a significant market niche that promotes economic and social development in urban and rural areas (Yun et al., 2011). Gastronomy can also be a new attraction by itself (Szívás, 1999), as well as the primary motive that meets a multitude of tourists' needs and desires. Gastronomic festivals are events that involve the whole local community in promoting local food (Everett, Aitchison 2007). They are also a place of social and cultural cohesion between communities, which brings in direct contact locals, visitors and organizers, encouraging the creatives and using specific local resources (Jamieson, 2014; Kwiatkowskia et al., 2019). Entrepreneurial potential of this events should be specially emphasized, because they can be start-ups for cobranding, testing new business ideas, co-creation and strengthening tourism operators' marketing (Dimitrovski, 2016; Hjalager, Kwiatkowski, 2018). Today's gastronomic festivals focused not only on delicious food, but also on delightful entertainment (Wu et al., 2014), and that why they are liminal areas in which the transformation of social space gives way to non-traditional behavior (Picard, Robinson, 2006).

When it comes to gastronomic festivals in rural area, one of the main obstacles is the lack of mapping of rural zones with specific specialties, as well as insufficient information and signalization. With clear promotion strategy tourist operators would have a better insight into the festival's offer (Grigorova et al., 2016). Despite the great potential of rural tourism, special emphasis has to be placed on ecology and sustainable development (Milićević et al., 2020).

The aim of this paper is to explore visitor's satisfaction with food offer at rural gastronomic festivals, as well as their experiences and habits. Based on the results of an empirical research of "Plum Fair" in Osečina, purpose is also to point out the potential of this type of festivals in the wider tourism market.

\section{Theoretical background}

In the last ten years, the number of researches of the food festival in rural areas has increased considerably, however, in literature are still dominating the publications of the food festival in the cities (Clark, Rice, 2019). The main focus of these researches is sustainability and revitalization of rural areas (Morgan, 2015; Black, 2016; Rinaldi, 2017; Wilson et al., 2017; Cong et al., 2019; ), impact on destination branding (Lee, Arcodia, 2011; Vukic et al. 2012; Blichfeldt, Halkier, 2014; Clark et al., 2019), impact on the local community (Alves et al., 2010; Smith, 2012; Nwokori, 2015; Ducros, 2018) as well as the motives and profile of visitors (Renting et al., 2003; Çela et al. 2007; Sidali et al., 2015; Eusébio et al., 2017; Kwiatkowskia et al., 2019). However, very few of the works dealt with the satisfaction of visitors with the gastronomic offer festival in rural areas (Wan, Chan, 2013; Bruwer, 2014; Jung et al, 2015; Markovic at al., 2015; Sohn et al., 2016; Lee at al., 2019). 
Gastronomic festivals in rural areas are usually small-scale events which aim is to have a presentation of characteristic local products such as different types of dishes, drinks, fruits and vegetables or varies kind of contests (Mogan, 2015; Krajíčková, Shauer, 2018). Visitors to these festivals are often ready to pay a higher price for unique specialties and experience (Renting et al., 2003), which often can be extended thanks to the consumption of these products at home (Sidali at al., 2015). Consumers' profile of these visitors is connected with higher education and belonging to medium-high class (Çela at al., 2007). As motives of visit, it has been specified desire to connect with the nature, environmental protection, search for authentic taste, support to the local producers (Sidali at al., 2015), but often as a dominant motive, it also extracts the desire for socializing (Eusébio et al., 2017; Kwiatkowskia et al., 2019). They can have a significant role in finding a solution to stop the weakening of the country's economic power and depopulation (Vukic et al., 2016). Food in terms of its diversity, quality and the price, was a decisive factor of visitors' satisfaction of many other kinds of festivals (Anil, 2012). The most often factors of satisfaction with rural food festivals were: attribute related to food, food uniqueness, staff quality, adequacy of information and facilities, programs, entertainment, creativity, hygiene (Vukić, 2015; Jung et al., 2015; Lee at al., 2019)

Not so few works dealt with the connection of gastronomies and rural areas in Serbia (Stojanović, 2013; Duvnjak at al., 2014; Vukić, 2015; Bjelja at al., 2016; Vujko et al., 2017; Cvijanovic, Ružić, 2017; Stanisic et al., 2018) however, according to the author's knowledge the subject none of those works was satisfaction of a visitor to gastronomic offer at the festivals in rural areas of Serbia. Using cluster analysis author Vukić (2015) revealed four segments of visitors in Serbia: "Rural gastronomies", "Gastronomic aesthetics”, „Tasters”, and „Gastronomic adventurers ". Although the "rural gastronomies was at least" the most important attributes when choosing the Festival were to be held in the rural environment and to offer local specialties. In the third place, was the duration of the festival tradition, while they were at least interested in the food presentation and entertainment. The largest number of gastronomic events in Serbia is organized at that time of year when the country attendance is the highest, but also that these events are not in the regions with the largest tourist traffic, so that we cannot link the number of tourist visits with the organizing of these festivals (Stanisic at al., 2018). The importance of food festivals is most reflected in the unadopted interaction agricultural producers and tourists, as well as market placement of national gastro products, providing spreading of positive image of Serbia as the destination of gastronomic tourism (Cvijanovic, Ružić, 2017; Vujko et al., 2017).

\section{Gastronomic manifestation in rural areas of Serbia}

In Tourism Strategy of the Republic of Serbia, events and festival are recognized as power means for destination branding (Novaković, Mandarić, 2019). Organizing different types manifestations can be adequate marketing strategy for overcoming seasonal character of tourist demand in rural areas (Grubor et al., 2019). The oldest 
tourist events in Serbia were dedicated to fruits and vegetables, and starting from the 1990s, the 20th century of this event is becoming more and more present (Bjeljac, 2006). On the territory of the Republic of Serbia, according to the event calendar, it is planned to be maintained 949 events of different categories and content in 2019 (National Tourism Organization of Serbia, 2019). Of the specified number, 369 are theatre manifestations, 3 of the general type, 111 is among the national creativity, 100 are gastronomic, congresses and fairs are 112 , economic is 87 , sports 138 , while holidays' is 39. From here, we can conclude that by the total number of manifestations, the events which as main aim have promoting of gastronomic product are on the third place. However, to those numbers of events surely can be added a certain number of manifestations that are presented in other categories, where visitors are offered promotions of gastronomic products.

The event, which as subject has plum and products of plums, is in very small numbers having in mind that Serbia is ranked fourth in the world, with a production of $400000 \mathrm{t}$ annually. In the Republic of Serbia, Plum is grown at $40 \%$ of total orchard area, while the region of Šmadija and western Serbia has the highest participation in production with $62.22 \%$ of total production (Statistical Office of the Republic of Serbia, 2018). Events that are being held in our country and are dedicated to the plum are only three: "The days of plum" in Blace", held from 22 $2^{\text {th }}$ August until 25 from $30^{\text {th }}$ August to $1^{\text {th }}$ September and ,Fair of schnapps“ from $28^{\text {th }}$ September until $29^{\text {th }}$ in Šljivovica (National Tourism Organization of Serbia, 2019). According to this information, it is possible to conclude that plum is fruits that in Serbia have a long tradition of breeding, but to promote this fruit and gastronomic products to its processing, it almost does not exist. That the patterns and gastronomic products of it may be a brand that will promote Serbia in the world, according to the fact that schnapps is registered on the list of the non-materialized cultural heritage of Serbia in October 2015 (Ministry of culture and information republic of Serbia, 2019).

When we are talking about rural manifestations in Serbia it is necessary to first define the term of the rural area. We can safely say that there is no a unique definition of this term. Organization for Economic Co-operation and Development (2018) distinguish rural regions close to cities from remote rural regions. As general criteria of rurality this organization states: dominant in agricultural surface, agriculture as base activities, weak population and low income. In Serbia, the Republican Institute of Statistics implements dichotomous division based on administrative and legal criteria, where urban and "other" settlements differ. Settlements that have a general urban plan are classified in urban, while other automatically are rural (www.stat.gov.rs, 2018). The municipality of Osečina with all surrounding municipalities can be considered as rural and according to the criteria of the OECD, but also the statistical Office of Serbia, because agriculture has over $66 \%$ of the territory, while $70 \%$ of the population deals with some other type of agricultural production. The production of plums, raspberries and blackberry are most present. There are about 800,000 plum trees in the municipality, which is a capacity of about 16000 tons (Municipality of Osečina, 2019). Recently, our country has adopted 
a number of economic policy measures, in order to stimulate agricultural production, such as subsidizing production, stimulating interest rates, writing off part of the debt to agricultural enterprises, reducing taxes (Pjanić et al., 2018) which can more increase production throughout Serbia as well as Western Serbia.

\section{Materials and methods}

In order to explore the experience and satisfaction of visitors to the food festival in rural area, study of local festival "Plum Fair" in Osečina was conducted. The municipality of Osečina is located in Western Serbia and consists of 20 settlements and 18 villages. The municipal seat is a village of Osečina which is $130 \mathrm{~km}$ away from Belgrade (Municipality of Osečina, 2019).

"Plum Fair" is an annual festival which has been held since 2006. And aims to affirm all resources that the municipality has. This manifestation was chosen because it is one of the few in the region of western Serbia and Sumadija that promotes the autochthon Serbian fruit varieties, as is the gastronomic products originating from it and are specific for the region.

The survey was conducted in August 2019 on the sample of 106 respondents. The general rule to calculate the sample size is to have a minimum of 5 observations per variable and maximum 10 observations per variable (Hair et al. 2014, Van Belle, 2011). In this study we have 11 variables, so we can consider sample size statistically significant. One part of the data was collected on the spot during the three days of the event, from August 30th to September 1st, while the second part was collected by the link of the survey through social networks to friends and friends of friends who have visited this event. The questionnaire specially created for this research, contained 3 sets of questions: demographic, tenth questions related to visitors' experience and habits, as well as four statements regarding visitors' satisfaction with food product. Visitors evaluated statements on a five-point Likert scale, where 1 stands for "Strongly Disagree", while 5 stands for "Strongly Agree". The collected data were analyzed using SPSS. Descriptive statistical analysis was used to describe respondents' demographic characteristics and to evaluate visitors' satisfaction, experience and habits. Spearman's rank correlation coefficient is used to examine correlation between satisfaction and visitors' habits, because Shapiro Wilk test of normality showed that the distribution of each variables is significantly different from normal.

\section{Results}

Demographic characteristics of visitors suggest that the number of female respondents is more than male. The largest number of respondents had graduated high school (45.3\%), while among them was equal number of employees $(44.34 \%)$ and unemployed $(42.45 \%)$. More than half of the visitors were over 36 years old. More detailed demographic information is in table 1. 
Table 1. Demographic structure of respondents

\begin{tabular}{|l|l|l|l|}
\hline \multicolumn{1}{|c|}{ Category } & \multicolumn{1}{|c|}{ Variable } & $\begin{array}{c}\text { No. of } \\
\text { respondent }\end{array}$ & \multicolumn{1}{c|}{$\%$} \\
\hline Gender & Male & 45 & 42.5 \\
\hline & Female & 61 & 57.5 \\
\hline Age & Under 18 & 19 & 17.9 \\
\hline & From 18 to 25 & 25 & 23.6 \\
\hline & From 26 to 35 & 11 & 10.4 \\
\hline & From 36 to 45 & 25 & 23.6 \\
\hline & From 46 to 60 & 14 & 13.2 \\
\hline & More than 60 & 12 & 11.3 \\
\hline & Primary school & 6 & 5.7 \\
\hline & High school & 48 & 45.3 \\
\hline & College & 16 & 15.1 \\
\hline & Faculty & 25 & 23.6 \\
\hline & Master & 11 & 10.4 \\
\hline Employee status & Phd & $/$ & $/$ \\
\hline & Employed & 47 & 44.3 \\
\hline & Unemployed & 45 & 42.5 \\
\hline & Retired & 14 & 13.2 \\
\hline
\end{tabular}

Source: Authors' calculations

\section{Analysis of visitors' experience and habits}

By analysis of the experience and habits of the visitors of the "Plum Fair" it was determined that the largest number of visitors have been informed about this manifestation through acquaintances (49.1\%) and social networks (23.6), while drastically less informed through other means $(9.4 \%)$, television commercials $(8.5 \%)$, flyers $(6.6 \%)$ and printed media (2.8\%). Since the largest number of visitors $(75.5 \%)$ were up to 45 years of age, it is logical that social networks were the basic source of information.

Visitors to this event came, in largest number, with friends $(32.1 \%)$ or family $(31.1 \%)$, then in the company of partners $(13.2 \%)$ and alone $(12.3 \%)$, and minority of them stated that they came with colleagues $(3.8 \%)$ and through organized tourism $(2.8 \%)$. The $4.7 \%$ stated as answer - the rest. A shared experience in gastronomic manifestations is exactly what makes them special. They can make a sense of togetherness, closeness that is increasingly losing in modern lifestyle. Offer of additional benefits such as entertainment, prize games, or themed lectures that are not primary when visiting gastronomic festivals, can increase the total created value of visitors that in this way satisfy their needs for socialization. It is needed a greater engagement of travel agencies that would include such events in their program, but also the tourism organizations that would invest more in the promotion of such events.

The largest number of visitors comes from Serbia $(82.1 \%)$ of which $70.1 \%$ are from places that are up to $50 \mathrm{~km}$. From the territory of the former Socialist Federal Republic 
of Yugoslavia comes $13.2 \%$, while only $4.7 \%$ came from the diaspora. As the event is attended predominantly by domicile population, this event ha local character. However, by linking this event to other tourism, such as rural, religious, spa or mountain it is possible to attract visitors from other parts of Serbia or the region, thus boosting the duration of stay in destination.

Regarding the frequency of the visit, half of the respondents $(57.5 \%)$ only once a year visit such events, $27.4 \%$ of respondents visit two to four times a year and only $15 \%$ visit more than 5 times. As the main motives of visits, the respondents stated the preservation of traditions $(28.3 \%)$, love of nature $(18.9 \%)$ and the atmosphere $(17 \%)$, a slightly smaller percentage as reasons stated socializing $(13.2 \%)$, while an equal number of visitors, i.e., $7.5 \%$ stated free tasting, curiosity and professional reasons as the main motive for the visit. It is interesting that research in the motives of visitors as a dominant motive has been extracted by the desire for socialization (Pesenos, 2015, Eusébio et al., 2017; Kwiatkowskia et al., 2019) while here is only in fourth place.

When visiting the most important attributes of the event are prices $(42.5 \%)$, product quality $(44.3 \%)$, while they are very little important to the aesthetics of products $(2.8 \%)$, exhibitor's hygiene $(1.9 \%)$, attendance $(0.9 \%)$ as well as availability of products only during the event (Unique Offer) (0.9\%). They 6.6\% of them cited other reasons. Such a small interest in the attributes of the unique offer can be connected with the visitors of this event mainly to the local that these products are easily available to. Since the highest number of visitors has purchased one of the gastronomic products $(68.9 \%)$ and $18.9 \%$ have declared that it is intended, we can conclude that this fair has a strong economic impact whether it is a direct and indirect expenditure of the participants. Only $12.3 \%$ of them did not buy anything. Also, the number of visitors said the offer of free tasting products was enough (49.1\%), even extremely rich (34.9\%), while 16\% were not satisfied. The main reasons for the purchase of gastronomic products were the desire to try something (32.1\%), support to local producers $(20.8 \%)$, impulsive purchase $(16 \%)$, professional reasons $(3.8 \%)$, desire to buy product as souvenir $(13.2 \%)$ and to conserve for more favorable prices $(14.2 \%)$.

\section{Visitors' satisfaction with food offer and correlation with their habits}

Apart from the habits of visitors of the event "Plum fair" in this paper, it has been analyzed their satisfaction with certain attributes of the exposed food products (Table 2). By observing the arithmetic mean of individual items of satisfaction factor, it can be noted that visitors are most satisfied with the taste of gastronomic products (means $=4.528$ ) and at least their price (means $=4.198$ ). The descriptive data for each feature of the gastronomic offer is in the Table 2 . 
Table 2. Structural view of summary satisfaction scale of gastronomic offer

\begin{tabular}{|l|l|l|r|r|}
\hline $\begin{array}{l}\text { Assess your satisfaction with the following attributes of } \\
\text { the exhibited gastronomic offer from 1 to 5 }\end{array}$ & means & St.dev & min & max \\
\hline Diversity & 4.4151 & 0.741529 & 1 & 5 \\
\hline Aesthetics & 4.4623 & 0.758125 & 1 & 5 \\
\hline Taste & 4.5283 & 0.807200 & 1 & 5 \\
\hline Price & 4.1981 & 0.960355 & 1 & 5 \\
\hline
\end{tabular}

Source: Authors' calculations

In addition to the satisfaction of certain features of the product, it is also calculated summed satisfaction of the gastronomic offer which is the sum of the scores on the questions attached in the table 2 and then divided with the number of questions. Central tendency measures, such as arithmetic mean and standard deviation, the summary scale of satisfaction said that respondents on average are satisfied with the offered products (means $=4.4$ ), and that the responses of the respondents are not different from each other $($ Std. Deviation $=0.70768)$. In order to calculate the reliability of the created scale of satisfaction, the Chrombach Alpha reliability test was used, which equals 0.884 , which showed that the data obtained in this survey may be considered as reliable.

Because the value of Chrombach Alpha, in case when each of the individual items would be thrown out, is less than Chrombach Alpha for the whole scale (table 3), the decision is to retain each of the item when creating the new satisfaction scale. Also, from the table can be seen how much each of the item contributes to explaining the summed satisfaction, where the diversity is most contributing to explaining satisfaction, since its value Corrected Item-Total Correlation the largest, i.e., it can be concluded that $67 \%$ of total satisfaction is explained only by the attributes of diversity, which shows the coefficient of determination which is obtained by squaring of the correlation coefficient.

Table 3. Structural view of summary satisfaction scale of gastronomic offer

\begin{tabular}{|l|r|r|r|r|}
\hline \multicolumn{1}{|c|}{ Indicators } & $\begin{array}{c}\text { Scale Mean if } \\
\text { Item Deleted }\end{array}$ & $\begin{array}{c}\text { Scale Variance if } \\
\text { Item Deleted }\end{array}$ & $\begin{array}{c}\text { Corrected Item- } \\
\text { Total Correlation }\end{array}$ & $\begin{array}{c}\text { Cronbach's } \\
\text { Alpha if Item } \\
\text { Deleted }\end{array}$ \\
\hline Diversity & 13.1887 & 4.802 & 0.819 & 0.829 \\
\hline Aesthetics & 13.1415 & 4.999 & 0.720 & 0.863 \\
\hline Taste & 13.0755 & 4.699 & 0.761 & 0.847 \\
\hline Price & 13.4057 & 4.224 & 0.726 & 0.869 \\
\hline
\end{tabular}

Source: Authors' calculations

In order to examine the connectivity of satisfaction with visitors ' habits, such as the distance from which they come, the frequency of visits, the offer of free products and the habit of purchasing, the correlation analysis was performed (table 4). For this purpose, Spearman's rho was used having in mind that Shapiro Wilk test of normality showed that the distribution of the above variables is significantly different from normal $(\mathrm{p}<0.05)$. 
Table 4. Spearman's rho

\begin{tabular}{|l|l|l|l|l|}
\hline & & Purchased product & Frequency & Satisfaction \\
\hline Distance & Correlation Coefficient & 0.272 & 0.365 & -0.90 \\
\hline & Sig. (2-tailed) & 0.005 & 0.000 & 0.361 \\
\hline $\begin{array}{l}\text { Free tasting } \\
\text { offer }\end{array}$ & Correlation Coefficient & 0.167 & 0.227 & 0.338 \\
\hline & Sig. (2-tailed) & 0.087 & 0.019 & 0.000 \\
\hline $\begin{array}{l}\text { Purchased } \\
\text { product }\end{array}$ & Correlation Coefficient & 1.00 & 0.313 & 0.049 \\
\hline & Sig. (2-tailed) & & 0.001 & 0.620 \\
\hline
\end{tabular}

Source: Authors' calculations

The results of the correlation analysis showed that there is a linear connection between the distances from which the visitors are coming and the frequency of the visit $(0365 ; \mathrm{p}$ $<0.01)$, distance and purchase of products $(0272 ; \mathrm{p}<0.05)$, frequency of the visit and offers of free products $(0227 ; p<0.05)$, frequency of visit and purchase of the product $(0313 ; \mathrm{p}<0.01)$, and between satisfaction of offer and offer of free products $(0338 ; \mathrm{p}$ $<0.01)$.

Also, based on the correlation results, the total satisfaction is not dependent on a gender, education, age or employment status of respondents, to what the value of Spearman's Rho $(\mathrm{P}>0.05)$ refers to.

\section{Conclusions}

Rural food products, as a part of national gastronomy, traditions and customs, represents a mirror of the material culture of one nation. Although gastronomic manifestations constitute only one tenth of the total number of events in Serbia, we are witnessing that this number has a trend of increasing. Rural areas of Western Serbia and Šumadija together with their natural and anthropogenic and ecological values can have a significant role in attracting tourists who search for authentic experiences and products. "Plum Fair" in Osečina is mainly visited by local visitors, so it is very important that the organizers pay more attention to the promotion of this festival in the other regions of Serbia or nearby countries. Better knowing the main motives, which were in this case preservation of tradition and nature, can help in creating additional content such as workshops about local herbal species, healthy eating habits, hiking, competitions or organize meals with locals in their home.

Such an event, can have a significant economic impact on all stakeholders, especially because of the high sale rate of food product. Since taste was the attribute with the highest score these products can be offered in local restaurants and hotels. With adequate branding strategy it is possible to increase the visibility of these products on the wither market by selling them in chains of hypermarkets, department stores and grocery stores. This idea derives from results of this study which showed that visitors who come from remote areas purchase more often than the other ones. 


\section{Conflict of interests}

The authors declare no conflict of interest.

\section{References}

1. Alves, H. M. B., Cerro, A. M. C., \& Martins, A. V. F. (2010). Impacts of small tourism events on rural places. Journal of Place Management and Development.

2. Anil, N. K. (2012). Festival visitors' satisfaction and loyalty: An example of small, local, and municipality organized festival. Turizam: međunarodni znanstvenostručni časopis, 60(3), 255-271.

3. Bjeljac, Z. (2006). Events in less developed regions of Serbia (Turisticke manifestacije u nedovoljno razvijenim prostorima Srbije). Bulletin of Serbian Geographical Society, 86(1), 245-256.

4. Bjeljac, Ž., Petrović, M., Terzić, A. (2016): Gastronomic events as a part of tourist offer: a case study of Serbia, Book of proceedings of IV International scientificpractical conference Sustainable development of tourism market: International practice and Russian experience, Stavropol, Russia, 11-16 March, 2016, pp. 12-17.

5. Black, N. H. (2016). Festival connections: How consistent and innovative connections enable small-scale rural festivals to contribute to socially sustainable communities. International Journal of Event and Festival Management.

6. Blichfeldt, B. S., \& Halkier, H. (2014). Mussels, tourism and community development: a case study of place branding through food festivals in rural North Jutland, Denmark. European Planning Studies, 22(8), 1587-1603.

7. Bruwer, J. (2014). Service quality perception and satisfaction: Buying behaviour prediction in an Australian Festivalscape. International Journal of Tourism Research, 16(1), 76-86.

8. Çela, A., Knowles-Lankford, J., \& Lankford, S. (2007). Local food festivals in Northeast Iowa communities: A visitor and economic impact study. Managing Leisure, 12(2-3), 171-186.

9. Clark, J., \& Rice, G. (2019). Revitalizing rural Scotland: Loch Fyne, branding and belonging. Journal of Place Management and Development.

10. Cong, L., Zhang, Y., Su, C. H. J., Chen, M. H., \& Wang, J. (2019). Understanding Tourists' Willingness-to-Pay for Rural Landscape Improvement and Preference Heterogeneity. Sustainability, 11(24), 7001.

11. Cvijanović, D., Ružić, P. (2017), Ruralni turizam, Fakultet za hotelijerstvo i turizam u Vrnjačkoj Banji, Vrnjačka Banja, Srbija.

12. Dimitrovski, D. (2016). Urban gastronomic festivals-Non-food related attributes and food quality in satisfaction construct: A pilot study. In Journal of Convention \& Event Tourism (Vol. 17, No. 4, pp. 247-265). Routledge. 
13. Domanović, V., Vujičić, M., \& Ristić, L. (2018), Profitability of food industry companies in the Republic of Serbia, Economic of Agriculture, 65(1), 11-32. doi:10.5937/ekoPolj1801011D

14. Ducros, H. B. (2018). "Fête de la Soupe": rural identity, self-representation, and the (re)-making of the village in France. Journal of Place Management and Development.

15. Duvnjak, N., Vrakela, J., Mlađenović, M., \& Petrović, N. (2014). Gastronomical manifestations in the tourism of South-Eastern Serbia. Researches Reviews of the Department of Geography, Tourism and Hotel Management, 43(2), 210-220.

16. Eusébio, C., Carneiro, M. J., Kastenholz, E., Figueiredo, E., \& da Silva, D. S. (2017). Who is consuming the countryside? An activity-based segmentation analysis of the domestic rural tourism market in Portugal. Journal of Hospitality and Tourism Management, 31, 197-210.

17. Everett, S., \& Aitchison, C. (2008). The role of food tourism in sustaining regional identity: A case study of Cornwall, South West England. Journal of sustainable tourism, 16(2), 150-167.

18. Grigorova, Z., Shopova, I \& Timareva, S. (2016). Rural food tourism,. Balkan and Near Eastern Journal of Social Sciences, 02(01), 35-41

19. Grubor, A., Leković, K., \& Tomić, S. (2019). Rural tourism marketing of the Danube region. Ekonomika, 65(4), 1-9.

20. Hair, J. F., Black, W. C., Babin, B. J., \& Anderson, R. E. (2014). Multivariate data analysis, 7th Edition. Pearson Education, Upper Saddle River.

21. Hjalager, A. M., \& Kwiatkowski, G. (2018). Entrepreneurial implications, prospects and dilemmas in rural festivals. Journal of Rural Studies, 63, 217-228.

22. Jamieson, N. (2014, January). Sport tourism events as community builders-how social capital helps the "locals" cope. In Journal of convention \& event tourism (Vol. 15, No. 1, pp. 57-68). Taylor \& Francis Group.

23. Jung, T., Ineson, E.M., Kim, M., Yap, M.H., (2015). Influence of festival attribute qualities on slow food tourists' experience, satisfaction level and revisit intention: the case of the mold food and drink festival. J. Vacat. Mark. 21 (3), 277e288.

24. Kim, Y. H., Duncan, J., \& Chung, B. W. (2015). Involvement, satisfaction, perceived value, and revisit intention: A case study of a food festival. Journal of culinary science \& technology, 13(2), 133-158.

25. Kim, Y. H., Duncan, J., \& Chung, B. W. (2015). Involvement, satisfaction, perceived value, and revisit intention: A case study of a food festival. Journal of culinary science \& technology, 13(2), 133-158.

26. Krajíčková, A., \& Šauer, M. (2018). Differences in motivation of food festivals visitors: A view from the Czech Republic. Geographica Pannonica, 22(3), 189-200. 
27. Kwiatkowski, G., Oklevik, O., Hjalager, A. M., \& Maristuen, H. (2019). The assemblers of rural festivals: organizers, visitors and locals. European Planning Studies, 1-18.

28. Lee, H., Hwang, H., \& Shim, C. (2019). Experiential festival attributes, perceived value, satisfaction, and behavioral intention for Korean festivalgoers. Tourism and Hospitality Research, 19(2), 199-212.

29. Lee, I., \& Arcodia, C. (2011). The role of regional food festivals for destination branding. International Journal of Tourism Research, 13(4), 355-367.

30. Markovic, S., Dorcic, J., \& Krnetić, M. (2015). Visitor satisfaction and loyalty measurement of a local food festival: Application of FESTPERF scale. In 3rd International Scientific Conference Tourism in Southern and Eastern Europe.

31. Mićović, A. (2017). Tourism Development and Evolution of Tourism Related Rules, 2nd International Scientific Conference - Thematic Proceedings II, Faculty of Hotel Management and Tourism, Vrnjačka Banja, 181-202.

32. Milićević, S., Đorđević, N., \& Krejić, Ž. (2020). Research on tourists' attitudes on the potential of Goč mountain for the development of eco-tourism. Economics of Agriculture, 67(1), 223-238.

33. Ministry of culture and information republic of Serbia (2019) (available at http:// www.nkns.rs/cyr/elementi-nkns).

34. Morgan, M. J. (2015). Food festivals, food marketing and the re-invention of a rural community. The Journal of New Business Ideas \& Trends, 13(2), 57.

35. Municipality of Osečina. (2019) (available at https://osecina.com)

36. National Tourism Organization of Serbia (2019). (available at: www.tos.rs)

37. Novaković, Đ. J., \& Mandarić, M. (2019). Do events contribute to the brand of Novi Sad? A millennials perspective.Hotel and Tourism Management,7(1), 47-59.

38. Nwokorie, E. C. (2015). Food tourism in local economic development and national branding in Nigeria. HATMAN Journal of Hospitality and Tourism, 5(1).

39. Organization for Economic Co-operation and Development (2018) (available at: https://www.oecd.org/cfe/regional-policy/Rural-3.0-Policy-Note.pdf).

40. Pesonen, J. A. (2015). Targeting rural tourists in the internet: Comparing travel motivation and activity-based segments. Journal of Travel \& Tourism Marketing, 32(3), 211-226.

41. Picard, D. \& Robinson, M. (Eds.) (2006). Festivals, tourism and social change: Remaking worlds. Clevedon: Channel View

42. Pjanić, M., Vuković, B., \& Mijić, K. (2018). Analysis of the market concentration of agricultural enterprises in AP Vojvodina. Strategic Management, 23(4), 40-45.

43. Renting, H., Marsden, T.K., \& Banks, J. (2003). Understanding alternative food networks: Exploring the role of short food supply chains in rural development. Environment and Planning A, 35(3), 393-411. 
44. Rinaldi, C. (2017). Food and gastronomy for sustainable place development: A multidisciplinary analysis of different theoretical approaches. Sustainability, 9(10), 1748.

45. Sidali, K. L., Kastenholz, E., \& Bianchi, R. (2015). Food tourism, niche markets and products in rural tourism: Combining the intimacy model and the experience economy as a rural development strategy. Journal of Sustainable Tourism, 23(8-9), 1179-1197.

46. Sims, R. (2009). Food, place, and authenticity: Local food and the sustainable tourism experience. Journal of Sustainable Tourism, 17(3), 321-336.

47. Smith, A. (2012). Events and urban regeneration: The strategic use of events to revitalise cities. Routledge.

48. Sohn, H. K., Lee, T. J., \& Yoon, Y. S. (2016). Relationship between perceived risk, evaluation, satisfaction, and behavioral intention: A case of local-festival visitors. Journal of Travel \& Tourism Marketing, 33(1), 28-45. doi:10.1080/10548408.20 15.1024912

49. Stanišić, T., Kostić, M., \& Mišeljić, M. (2018). Gastronomic manifestations as a factor of improvement of serbia's tourism offer. Economics of Agriculture, 65(1), 111-124.

50. Statistical Office of the Republic of Serbia (2018): Farm structure survey, 2018. (available at: https://publikacije.stat.gov.rs/G2019/Pdf/G20196004.pdf).

51. Stojanović, D. (2013). Gastronomija kao faktor razvoja ruralnog turizma, master teza Univerzitet Singidunum, Beograd, Srbija.

52. Stošić, L., \& Stošić, I. (2013). Diffusion of innovation in modern school. International Journal Of Cognitive Research In Science, Engineering And Education (IJCRSEE), 1(1), 12-24.

53. Szivas, E (1999). The development of wine tourism in Hungary. International Journal of Wine Marketing, 11(2), 7-17.

54. Van Belle, G. (2011). Statistical rules of thumb. John Wiley \& Sons.

55. Vujko, A., Petrović, M. D., Dragosavac, M., Ćurčić, N., Gajić, T. (2017): The linkage between traditional food and loyalty of tourists to the rural destination, Teme, vol. XLI, no. 2, pp. 475-487, University of Niš, Niš, Serbia

56. Vukić, M. (2008) Osnovi gastronomije. Visoka hotelijerska škola, Beograd

57. Vukic, M., Kuzmanovic, M., \& Vukic, K. (2016). Gastronomic festivals as a form of branding Serbia as a tourist destination. In Proceedings of the XV International Symposium SYMORG 2016 (pp. 913-919).

58. Vukic, M., Popovic, M. \& Kuzmanovic, M. (2012). Branding in Serbian Rural Tourism. Journal of Economics and Behavioral Studies, 4(11), 671-676.

59. Wan, Y. K. P., \& Chan, S. H. J. (2013). Factors that affect the levels of tourists' satisfaction and loyalty towards food festivals: A case study of Macau. International journal of tourism research, 15(3), 226-240. 
60. Wilson, J., Arshed, N., Shaw, E., \& Pret, T. (2017). Expanding the domain of festival research: A review and research agenda. International Journal of Management Reviews, 19(2), 195-213.

61. Wu, H.-C.,Wong, J.W.-C., \& Cheng C.-C. (2013). An empirical study of behavioral intentions in the food festival: The case of Macau. Asia Pacific Journal of Tourism Research, 19(11), 1278-1305. doi:10.1080/10941665.2013.844182.

62. Yun, D., Hennessey, S. M., \& MacDonald, R. (2011). Understanding culinary tourists: Segmentations based on past culinary experiences and attitudes toward food-related behaviour. (available at: https://scholarworks.umass.edu). 